\title{
Social Construction of "Fisherman": Fisherman is Always Man, Women Loss Their Privileges
}

\author{
Sigit Andrianto \\ Department of Communication, Faculty of Social and Political Science Universitas Diponegoro, Semarang - Indonesia
}

\begin{abstract}
Several areas in Indonesia, including in Purworejo villages, Demak regency of Central Java, women went to sea to catch fish. Unfortunately, there are no guarantee of safety for women. They do not get any insurance from the government, because they dont have "Kartu Nelayan" (card for fishers). Although the government already has a protection program for fishers, women are always left out from this program. This study uses Phenomenology to describe how ideology is maintained in the society. This study found that the discourse of fisherman continues to be maintained, even unconsciously, by women themselves in their struggle. The social construction or the ideology about fisherman, that fisherman always a man, put women on the second class. Even though they go to sea, with the same workload and risk, they are only considered just to "help" their husband's economy. This study argues, to change this situation, it is required to change the social order fundamentally.
\end{abstract}

Keywords: Fisherman; Ideology; Inequality.

\section{Introduction}

Indonesian government provides social assistance to fishers as compensation for subsidized fuel price increases. Assistance is provided in the form of fishing nets, ship engines, and cooling boxes. To facilitate in giving this assistance, government launched Kartu Nelayan [1]. Beside to facilitate the government in distributing assistances, Kartu Nelayan also as one of requirement for the fishers to be a recipient of an insurance program called Bantuan Premi Asuransi Nelayan (BPAN) from the government. This program gives benefit value for every fishers to get compensation when they got an accident in the fishing activity of Rp200 million (if death), Rp100 million (if causing permanent disability) and Rp20 million (for medical expenses) [2]. Without a Kartu Nelayan, fishers would not be able to obtain this safety guarantee program.

Some fishers in Purworejo Village, Bonang Subdistrict, Demak Regency have been enrolled in this BPAN program. Unfortunately none of the women in this village are registered because they do not have Kartu Nelayan. In fact, the women also do work according to the definition of Fishermen in Article I point 3 of Law No. 7 of 2016 on Protection and Empowerment of Fisherman in Fish Cultivations and Salt Farmers reveald that Fishers are those whose work is fishing.

Economic limitations make about $50 \%$ of women in Purworejo Village go out to the sea to catch fish, crabs, sodo and some other sea products for years. This data collected from the fishers (women) themselves, because the government, especially the lowest government or village level has not recognized women as fishers (this data collected from interview with women's associations). The absence of recognition from the village and community make women unable to get their rights, including the right to get an insurance.

From this background, the research question arises, how the patriarchal ideology has been maintained for many years by the people in Purworejo Village, Demak District which then raised oppression for woman in this place?.

\section{Methodology}

Using Phenomenological approach, this paper explores how women's experiences in the man ideology. According to critical view Ideology has been shrouded in the various of life in modern society that giving a benefit to certain parties [3]. In phenomenology, Edmund Husserl explains that the relationship between perception and object is not passive. Human consciousness actively defines the experience of the object [4]. In this study data collection was done by conducting direct interviews with the perpetrators and observation by following informants activities. 


\section{Discussion}

The problem of gender inequality arises when there is a right of one party in Purworejo Village society is not fulfilled. Until now still maintained public opinion that women can not be called as fishers even though they do the work of fishers. This assumption is believed to be something that is granted until now. Of course this assumption does not fit with the opinion of Peter Berger, that the social order is not something given. Rather, human products are produced continuously [5]. Construction takes place continuously in social interaction. Then by habituation, people do not need to define the situation in the future.

Including the meaning of fisherman who constructed by community of Purworejo Village. Fisherman are man, who can face the viciousness of the ocean and culturally run by men since ancient times. Culturally, fisherman are not women. Society also construct the meaning of wife. Based on the social background of the community as a Muslim society, the obedience of the wife to the husband becomes the main thing. Whatever is done by the wife solely for the obedience to their husband.

These meanings are constructed by society continuously. Furthermore, through habituation society accepts this meaning as something ordinary in their life. So it will not bring up a questions even when the rights of one party have been violated.

This cultural construction then places women in the domestic or household sector. That is, the main task of women is to take care of the household and cultivate the fish catch by man from the sea. So even some women go to sea, the assumption as a housewife is still attached to them. Because their fishing activity is only considered as helping the husband. This definition then hampers the efforts of women to fight for their rights by changing jobs in their own identity columns.

Maintenance of patriarchal ideology in life can not be separated from the role of language. Bordieu views language not only as a means of communication, but also as a means of achieving goals [6]. This is based on the view that social relations are essentially relations of domination so that communication relations are characterized by the exchange of discourse as a symbolic power relation.

In Purworejo society life, language plays an important role in making women feel that it has become her nature to serve their husband. The discourse of Perempuan Nelayan as a wife who must serve the husband makes the woman feel quite enough only the husband who obtained Kartu Nelayan. Even they are forget when in the ocean, their bodies are not covered by the same insurance. In the sense that, when facing an undesirable event, only man will get insurance coverage from the government.

Other than society's perception of women role, environment take a big role to limit women to get a job. Especially in Purworejo, hot, rocky, and coastal beach environment forcing women not to interfere in matters relating to fisherman. Those rough environment forces man to play a role in finding work especially being a fisherman. This kind of things force women to deal only with household.

Wittgenstein states that facts, reality, or language games can be seen as meaningful in their use [7]. Behind the expression of language, hidden the latent anthropocentric form the people expressed this language. In this case, the meaning of Perempuan Nelayan is not necessarily interpreted as a fishers. But the meaning depends on perceptions based on cultural, educational and socio-economic background. The expression of Perempuan Nelayan can be interpreted as an effort of women exclusion from fisherman job.

J.L. Austin mentions three aspects of language meaning [6]. The first is the locutionary aspect, that is, the object of discourse analysis depends on the meaning of discourse. The second aspect is illocutionary, explains that each statement has subject implications for the speaker. The use of the term Perempuan Nelayan in Purworejo society raises the implication of the speaker, that is asking. Asking woman to perform their duties as women in the family. The last aspect is perlocutionary, which leads to an effect on the other person. In the discourse of Perempuan Nelayan, the effect that arises is the adherence to the construction of a wife who is obliged to obey the husband.

This discourse certainly give benefit to the man. Perpetuate their position on the community construction as a fisherman, while women with the same jobs and risks are only labeled as family or fishermen's wife. By using Perempuan Nelayan terms, the existing patriarchal ideology is preserved and instilled in the minds of the society. People, especially man, retain power by placing women in the position of "the other".

Simone De Beauvoir explains why this condition arises. According to Beauvoir, when men look at themselves as subjects, woman views as "the other" will appear. Woman, must controlled by man, because if not, women will become self and men become "the other" [8]. Woman in this case are not given the opportunity to view themselves as self. So it has implications on various forms of oppression [3]. One form of oppression that emerged later was the shifting role of women in the public sector without abandoning the "obligations" in the domestic.

Double roles are performed by women doing jobs in the household sector as well as the economic sector. In the household sector women are burdened with the work of preparing food to go to sea, and processing fish catched by man. While in the economic sector they also have to go to sea in terms of production until selling the products in the market. If the work of the fishers is deemed to be performed only by men, then the granting of permits to women to work in the oceans is one form of exploitation by men to the woman.

Until now, people can not recognize women who go to sea as fishers. Communities, including village officials, think that women only help their husbands when they go to the sea. So there is a grouping of phrase Fisherman, Fisherman Families and Perempuan 
Nelayan. As an excerpt from an interview with the Purworejo village chief:

"Culturally it is proper to be called a fisherman is a man, because from the first this job was done by man. If women consider themselves to be fishers, $\mathrm{i}$ think it becomes something strange. I think they are not fisherman, but fisherman's families."

Some women who aware to their rights try to change the work columns in their identity cards. Change of identity card can open access to women to get safety guarantee. Because by being recognized administratively, women will be able to claim their rights as fishers. But, the village chief always objected with the reasons he will think twice for this proposal.

Only a few women are aware to their rights. There are still many women who are still bound by the rules of society that their duty is solely to serve their husbands. Moreover, the characteristics of Demak as a Muslim-based city make women will prioritize obedience to their husbands. As expressed by women who went to sea:

"Because of the economic demands, we have to go to sea. If we can not eat, we might get angry from our husband. Life on the coast was hard. And as a wife we do have to obedience to our husband."

\section{Conclusion}

The perpetuation of patriarchal ideology is done by Purworejo Village community by using cultural beliefs which are constructed continuously. The belief that only man are able to cope with the viciousness of the oceans, only men who are culturally work and has responsibilities as a fishers, the belief that women have a central role in the domestic sphere. This cultural belief prevents women from getting their rights. With this belief, woman experience exploitation by carrying out multiple roles in life. Not getting insurance becomes more than enough evidence that patriarchal ideology is still in power in the life of the Purworejo community.

Equality between men and women becomes a very important thing to strive for. So it needs a fundamental change in the mindset of the people in Purworejo Village that culture is the result of community construction. So that there will be an understanding to fulfill the rights of each other.

\section{References}

1. Kontan Mobile, Jokowi akan Kembali Luncurkan Kartu Nelayan, Retrieved from www.kontanmobile.com on 5 September 2017 (2014).
2. Kompas.com, Seperti Apa Program Asuransi bagi Nelayan yang Disediakan Pemerintah?, Retrieved from www.kompas.com on 5 September 2017 (2017).

3. F. B. Hardiman, Kritik Ideologi, Menyingkap Pertauatan Pengetahuan dan Kepentingan Bersama Jurgen Habermas, Kanisius, Daerah Istimewa Yogyakarta (2009).

4. N. K. Denzin, S. Lincoln Yvonna, The Sage Handbook of Qualitative Research, Third Edition, SAGE Publications, London (2005).

5. P. L. Berger, T. Luckmann, Tafsir Sosial atas Kenyataan, Terj. M Frans Parera, LP3ES, Jakarta (1990).

6. Haryatmoko, Critical Discourse Analysis. Landasan Teori, Metodologi dan Penerapan, Rajawali Pers, Jakarta (2017).

7. W. Wibowo, Menuju Jurnalisme Beretika, Peran Bahasa, Bisnis dan Politik di Era Mondial, PT Kompas Media Nusantara, Jakarta (2009).

8. R. P. Tong. Feminist Though, Pengantar Paling Komprehensif kepada Arus Utama Pemikiran Feminis. Yogyakarta, Jalasutra (2010).

9. S. D. Beavoir, Second Sex, Kehidupan Perempuan, Terj Toni B Febriantono, Nuraini Juliastuti, Narasi, Yogyakarta (2016).

10. UU Nomor 7 tahun 2016 tentang Perlindungan dan Pemberdayaan Nelayan Pembudidaya Ikan dan Petambak Garam (2016) 